CZU:635.655:631.523:577.112(560) ｈttps://doi.org/10.53040/gppb7.2021.100

\title{
OIL, PROTEIN CONTENT AND FATTY ACID COMPOSITIONS OF SOYBEAN GENOTYPES EVALUATED IN DOUBLE CROPPING SYSTEM AT THE EASTERN MEDITERRANEAN IN TURKEY
}

\author{
Cubukcu Pınar, Sahar Korhan A., Oluk C. Aylin \\ Eastern Mediterranean Agricultural Research Institute (EMARI) \\ e-mail: pcubukcu@hotmail.com
}

\begin{abstract}
Soybean (Glycine max (L.) Merrill) is very important crop for food, protein, and oil both human and animal feeding. The aim of this study determinate oil ratio, protein ratio and fatty acid compositions of Soybean breeding lines developed from Eastern Mediterranean Agricultural Research Institute (EMARI). This study was conductucted in double cropping system at the Eastern Mediterranean Agricultural Research Institute ( EMARI), Turkey in 2019 growing seasons. Through this study, it was realised that the fatty acid composition of soybean lines ranged from 11.34-9.80 for palmitic acid, 4.30-6.54\% for stearic acid, $26.16-34.11 \%$ for oleic acid, $42.82-48.12 \%$ for linoleic, and $4.54-5.43 \%$ for linolenic acid in double cropped soybean. Oil content was found $22.4 \%$, protein content was $40.9 \%$ DA $12-14-3$ and DA 12-15-39-40 soybean lines repectively.
\end{abstract}

Key words: genotype, soybean, oil, protein, fatty acids,double cropping. 